\title{
Improvement of the wet-oxidation procedure for simultaneous determination of particulate organic nitrogen and phosphorus collected on filters
}

\author{
M. Pujo-Pay, P. Raimbault \\ Centre d'Océanologie de Marseille, Faculté des sciences de Luminy, Case 901, F-13288 Marseille cedex 9, France
}

\begin{abstract}
A new digestion technique is presented for simultaneous analysis of particulate organic nitrogen (PON) and particulate organic phosphorus (POP) collected on filters This method is based on a standard persulfate digestion procedure at $120^{\circ} \mathrm{C}$ and adapted from a former method for the simultaneous determination of total nitrogen and total phos phorus in natural waters. Comparisons with usual methods using separate determinations for PON and POP indicate a high efficiency of the procedure for cell cultures or natural seawater samples. Nitrate and phosphate formed by oxidation can be analysed simultaneously on an automated system. The procedure is highly suitable for routine analysis and especially appropriate for shipboard use.
\end{abstract}

KEY WORDS: Wet oxidation - Particulate nitrogen Particulate phosphorus

Particulate organic nitrogen (PON) and particulate organic phosphorus (POP) collected on filters are normally still determined by separate procedures for each element. PON is conventionally determined by dry combustion followed by $\mathrm{N}_{2}$ analysis on a $\mathrm{CHN}$ analyser, but the feasibility of using an efficient wetoxidation procedure was recently pointed out (Raimbault \& Slawyk 1991). On the other hand, particulate phosphorus is currently determined with the wet-oxidation method of Menzel \& Corwin (1967). Up until now, there has been no procedure allowing the simultaneous determination of particulate nitrogen and phosphorus collected on the same filter. However, several new techniques have been developed for simultaneous analysis of total organic nitrogen and phosphorus, including dissolved (DON, DOP) and particulate fractions (PON, POP), in natural waters (Valderrama 1981, Langner \& Hendrix 1982, Ebina et al. 1983, Koroleff 1983, Hosumi \& Sudo 1986, Johnes \& Heathwaite
1992). The main problem with simultaneous determination of PON and POP is that nitrogen oxidation requires an alkaline medium while phosphorus analysis requires acidified samples. Valderrama (1981) and Johnes \& Heathwaite (1992) resolved this problem by using a variable $\mathrm{pH}$ reagent. Their initially basic oxidative medium became acidic during the oxidation, by decomposition of persulfate to sulphuric acid at high temperature. These conditions can be obtained by increasing the quantity of persulfate (Johnes \& Heathwaite 1992) or by adding boric acid (Valderrama 1981). Nevertheless, none of these authors tested this digestion procedure for the particulate fraction collected on filters. Based on Valderrama's (1981) method and on the previous results obtained for PON by Raimbault \& Slawyk (1991), this note presents a procedure for simultaneous analysis of PON and POP collected on the same filter. The method exhibits very good reliability and precision in comparison with former procedures.

Two examples of application are presented here. (1) The procedure was applied to describing the vertical distribution of PON and POP and the PON/POP ratio in the Tropical Atlantic Ocean. (2) The technique was applied to following PON and POP accumulation in various phytoplankton cultures growing on nitrate and phosphate.

Material and methods. PON and POP from phytoplankton cultures or natural seawater were collected by filtration on precombusted $\left(450^{\circ} \mathrm{C}\right.$ for $4 \mathrm{~h}$ ) Whatman $\mathrm{GF} / \mathrm{F}$ glass fibre filters (25 $\mathrm{mm}$ diam.). Filters were initially rinsed in $\mathrm{HCl}(10 \%)$ and cleaned with deionized water (DIW) just before filtration. This previous cleaning allowed reduced filter blanks. Samples of 150 to $250 \mathrm{ml}$ were filtered for the oxidation method, while 1 to 21 were required for the dry combustion method. 
If analyses were not done immediately, filters were either dried at $60^{\circ} \mathrm{C}$ for $24 \mathrm{~h}$ and stored in a dessicator or deep-frozen until analysis.

Reagent: The oxidising reagent was prepared using the following procedure: $15 \mathrm{~g}$ of potassium persulfate (Merck 5092) and $7.5 \mathrm{~g}$ of boric acid (Merck 165) were dissolved with $70 \mathrm{ml}$ of $1.5 \mathrm{M}\left(60 \mathrm{~g} \mathrm{I}^{-1}\right)$ sodium hydroxide (Merck 6498) and made up to $250 \mathrm{ml}$. The DIW used for the preparation of this oxidation mixture was Milli-Q water (resistivity $18.2 \mathrm{~m} \Omega$ ). The oxidative reagent was stored in brown bottles at room temperature and protected from direct light. It was prepared fresh daily to be sure of maximum efficiency.

Procedure: Digestions were carried out in $30 \mathrm{ml}$ Teflon bottles with screw caps. Traces of organic matter from the bottles were completely removed by washing them with $\mathrm{HCl}$ solution $(10 \%)$ and submitting them to a preliminary digestion (without sample). Twenty millilitres of DIW and $2.5 \mathrm{ml}$ of reagent were dispensed into the Teflon bottles. The initial $\mathrm{pH}$ of the mixture was basic ( $\mathrm{pH}=11.2$ to 11.5 ). The GF/F filters retaining the particulate matter were placed in the bottles which were then tightly capped and autoclaved at $120^{\circ} \mathrm{C}$ for $30 \mathrm{~min}$. After oxidation, the $\mathrm{pH}$ of the assay mixture decreased and became acid, $\mathrm{pH}=\mathrm{ca} 1.7$ to 2.3 .

After cooling to room temperature, nitrate $\left(\mathrm{NO}_{3}\right)$ and phosphate $\left(\mathrm{PO}_{4}\right)$ concentrations were determined in the digested sample using an automated colorimetric technique on a Technicon Auto Analyser (Tréguer \& Le Corre 1975). A blank was made in replicate with each batch of samples.

To determine the blank, the same volume of oxidation reagent used to analyse the samples was added to $20 \mathrm{ml}$ DIW containing a precombusted and rinsed filter. The filters used for the blanks were previously placed on the filtration system in order to reproduce the same experimental conditions as those of the samples. Total blank (digestion reagent + DIW + filter) gave a $\mathrm{NO}_{3}+\mathrm{NO}_{2}$ concentration of $0.81 \pm 0.16 \mu \mathrm{M}$ and a $\mathrm{PO}_{4}$ concentration of $0.258 \pm 0.037 \mu \mathrm{M}(\mathrm{n}=17)$. The reagent blank, obtained by oxidising $2.5 \mathrm{ml}$ reagent, was $0.34 \pm 0.02 \mu \mathrm{M}(\mathrm{n}=17)$ and $0.018 \pm 0.006 \mu \mathrm{M}(\mathrm{n}=$ 18) for $\mathrm{N}$ and $\mathrm{P}$ respectively. In fact, the contribution of the filter to the total blank was very low: about $0.01 \mu$ mol P per filter.

The acid $\mathrm{pH}$ of the assay mixture after digestion did not interfere with the $\mathrm{PO}_{4}$ analysis. However, a neutralisation of $\mathrm{pH}$ is required for the nitrate analysis. The reduction of nitrate to nitrite by a $\mathrm{Cd}-\mathrm{Cu}$ column is efficient only at $\mathrm{pH} 8$. Preliminary tests showed that the conventional Technicon manifold for $\mathrm{NO}_{3}+\mathrm{NO}_{2}$ determination (Strickland \& Parsons 1972, Tréguer \& Le Corre 1975) can be modified slightly to permit a buffer $\left(\mathrm{NH}_{4} \mathrm{Cl}, 150 \mathrm{~g} \mathrm{l}^{-1}, \mathrm{pH}=8.5\right)$ to be added to
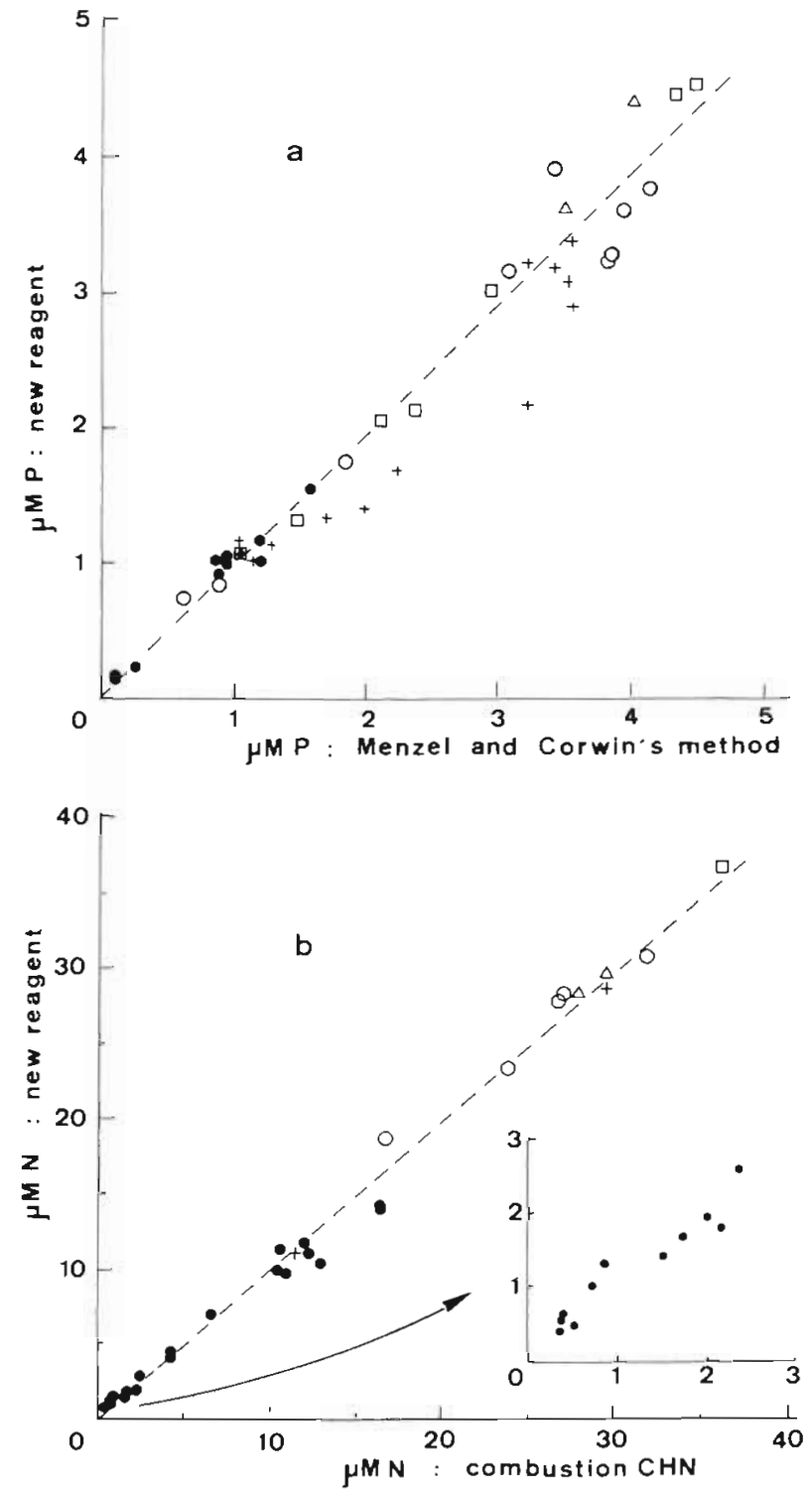

Fig. 1. Comparison between the new procedure and (a) Menzel \& Corwin (1967) oxidation for POP; (b) the dry-combustion method (CHN) for PON determination on natural $(\bullet)$ and culture samples (t, Synechococcus sp.; $\square$, Phaeodactylum tricornutumi $_{i} \Delta$, Dunaliella tertiolecta; 0 . Tetraselmis maculata). Natural samples were from a coastal zone and an open ocean zone (Tropical Atlantic). Dashed lines are the least-square regression fit. For PON, $y=0.997 x-0.171 ; \mathrm{r}^{2}=0.996, \mathrm{n}=33$. Inset is an enlargement of the data at low concentrations. For POP, $y=0.968 x+1.173 \times 10^{-2} ; r^{2}=0.967 ; n=49$

the sample before adding analytical reagents, with a sample:buffer ratio of $10: 1\left(0.32 \mathrm{ml} \mathrm{min}^{-1}\right.$ of sample; $0.03 \mathrm{ml} \mathrm{min}{ }^{-1} \mathrm{NH}_{4} \mathrm{Cl}$ ). Just before analysis, samples were filtered in order to eliminate filter fragments.

For PON, values were compared with those obtained by high temperature, dry combustion $\left(900^{\circ} \mathrm{C}\right)$ in the laboratory or with the wet-oxidation method (Raim- 
Table 1. Statistical analysis of replicate PON and POP determinations by the new method. $\mathrm{n}$ : number of samples

\begin{tabular}{|c|c|c|c|c|c|c|}
\hline Sample & Element & $\mathrm{n}$ & $\begin{array}{l}\text { Mean concentration } \\
(\mu \mathrm{M})\end{array}$ & $\begin{array}{l}\text { Standard } \\
\text { deviation }\end{array}$ & $\begin{array}{l}\text { Variation } \\
\text { coefficient }(\%)\end{array}$ & $\begin{array}{l}\mathrm{PON} / \mathrm{POP} \\
\text { ratio }\end{array}$ \\
\hline $\begin{array}{l}\text { Natural seawater (upwelling } \\
\text { off Mauritania) }\end{array}$ & $\begin{array}{l}\text { PON } \\
\text { POP }\end{array}$ & $\begin{array}{l}5 \\
5\end{array}$ & $\begin{array}{l}4.21 \\
0.3\end{array}$ & $\begin{array}{l}0.18 \\
0.03\end{array}$ & $\begin{array}{l}4.3 \\
10\end{array}$ & 14 \\
\hline Synechococcus sp. & $\begin{array}{l}\text { PON } \\
\text { POP }\end{array}$ & $\begin{array}{l}2 \\
5\end{array}$ & $\begin{array}{c}29.5 \\
3.48\end{array}$ & $\begin{array}{l}1.3 \\
0.06\end{array}$ & $\begin{array}{l}4.4 \\
1.7\end{array}$ & 8.47 \\
\hline Phaeodactylum tricornutum & $\begin{array}{l}\text { PON } \\
\text { POP }\end{array}$ & $\begin{array}{l}5 \\
5\end{array}$ & $\begin{array}{r}25.13 \\
3.76\end{array}$ & $\begin{array}{l}1.82 \\
0.35\end{array}$ & $\begin{array}{l}7.2 \\
9.3\end{array}$ & 6.68 \\
\hline P. tricornutum & $\begin{array}{l}\text { PON } \\
\text { POP }\end{array}$ & $\begin{array}{l}4 \\
4\end{array}$ & $\begin{array}{r}25.17 \\
3.69\end{array}$ & $\begin{array}{l}2.34 \\
0.14\end{array}$ & $\begin{array}{l}9.3 \\
3.9\end{array}$ & 6.82 \\
\hline Tetraselmis maculata & $\begin{array}{l}\text { PON } \\
\text { POP }\end{array}$ & $\begin{array}{l}3 \\
3\end{array}$ & $\begin{array}{c}22.41 \\
2.9\end{array}$ & $\begin{array}{l}1.52 \\
0.17\end{array}$ & $\begin{array}{l}6.8 \\
5.9\end{array}$ & 7.72 \\
\hline
\end{tabular}

bault \& Slawyk 1991) during shipboard analysis. The high temperature determinations were performed with a CHN LECO analyser with glycine as a standard. For this analysis, a large quantity of organic matter is required and 0.5 to 21 of samples must be filtered.

POP values were compared with those obtained by the procedure of Menzel \& Corwin (1967) where the acid reagent completely oxidises phosphorus but does not permit complete oxidation of nitrogen. In this method, $2.5 \mathrm{ml}$ of a freshly prepared solution of $6 \%$ $\mathrm{K}_{2} \mathrm{~S}_{2} \mathrm{O}_{8}$ is placed in a $30 \mathrm{ml}$ Teflon bottle containing the filter and $20 \mathrm{ml}$ of DIW. The solution is autoclaved for $30 \mathrm{~min}$ at $120^{\circ} \mathrm{C}$. After cooling, the phosphate $\left(\mathrm{PO}_{4}\right)$ concentration is determined on a Technicon Auto Analyser as described above. As a result of the decomposition of $\mathrm{K}_{2} \mathrm{~S}_{2} \mathrm{O}_{8}$, the $\mathrm{pH}$ of the sample following oxidation is reduced to between 1.5 and 1.8 because of the production of $\mathrm{H}_{2} \mathrm{SO}_{4}$, but this does not interfere with the subsequent colorimetry. Another decomposition product is $\mathrm{H}_{2} \mathrm{O}_{2}$, and considerable quantities of free chlorine are liberated, producing a highly oxidative atmosphere.

In the field, profiles of PON, POP and PON/POP ratio were compared with the vertical distributions of chlorophyll determined by fluorimetry according to Raimbault et al. (1988).

Results and discussion. Comparison of the simultaneous analysis method applied to cultures or natural seawater samples showed excellent agreement with previous methods for determination of PON and POP (Fig. 1). The recovery was close to $100 \%$ (95\% confidence limit of 0.01 ) with a very low standard deviation over a wide range of concentrations. Thus, we can assume that this new reagent recovered the whole of the $\mathrm{N}$ and $\mathrm{P}$ from living phytoplankton and other marine organic particles. The thoroughness and precision of the method were checked by analysis of replicate PON and POP determinations of different cultures and natural seawater samples using the method (Table $1)$. The standard deviation is low $(<10 \%)$. The present procedure (in $22.5 \mathrm{ml}$ of assay mixture) is applicable for low PON and POP concentrations, making it suitable for use in oceanic waters. A further example of vertical PON and POP distributions in oceanic seawater (Tropical Atlantic) confirmed the good correlation between the different techniques (Fig. 2). The distribution of particulate nitrogen and phosphorus was well
Fig. 2. Vertical distributions of (a) PON and (b) POP fractions collected on filters determined either by usual methods ( $\bullet$ ) or by the new reagent (O). (c) Profiles of the PON/POP ratio (+) compared to the vertical chlorophyll distributions (ㅁ). These values were derived from the EUMELI cruises in the open Tropical Atlantic Ocean
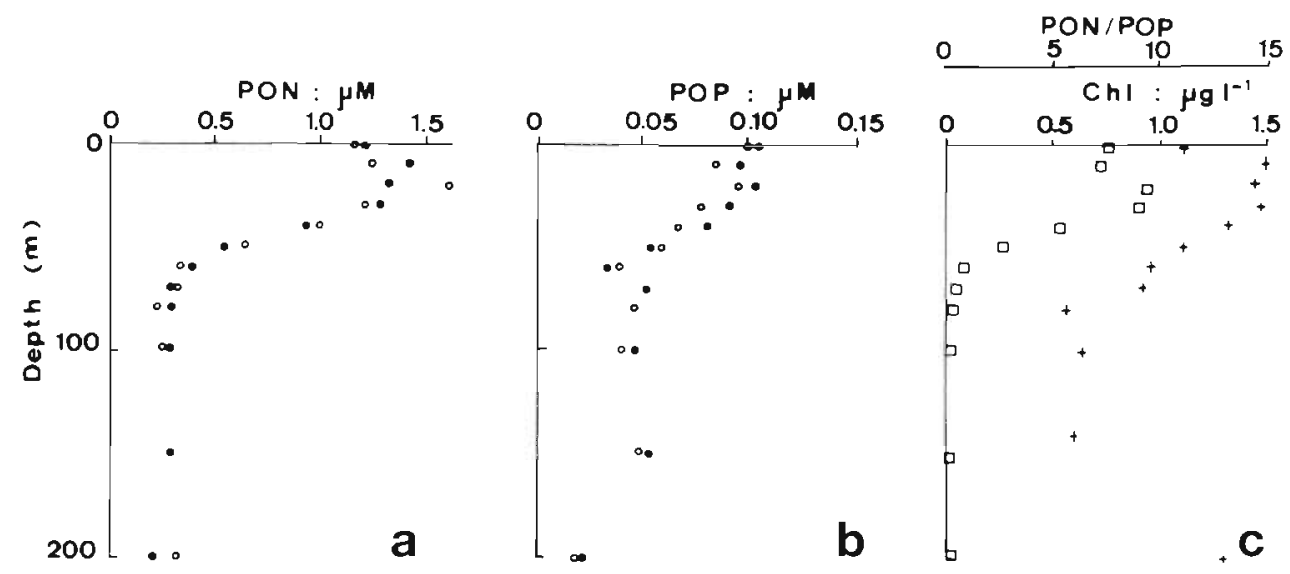

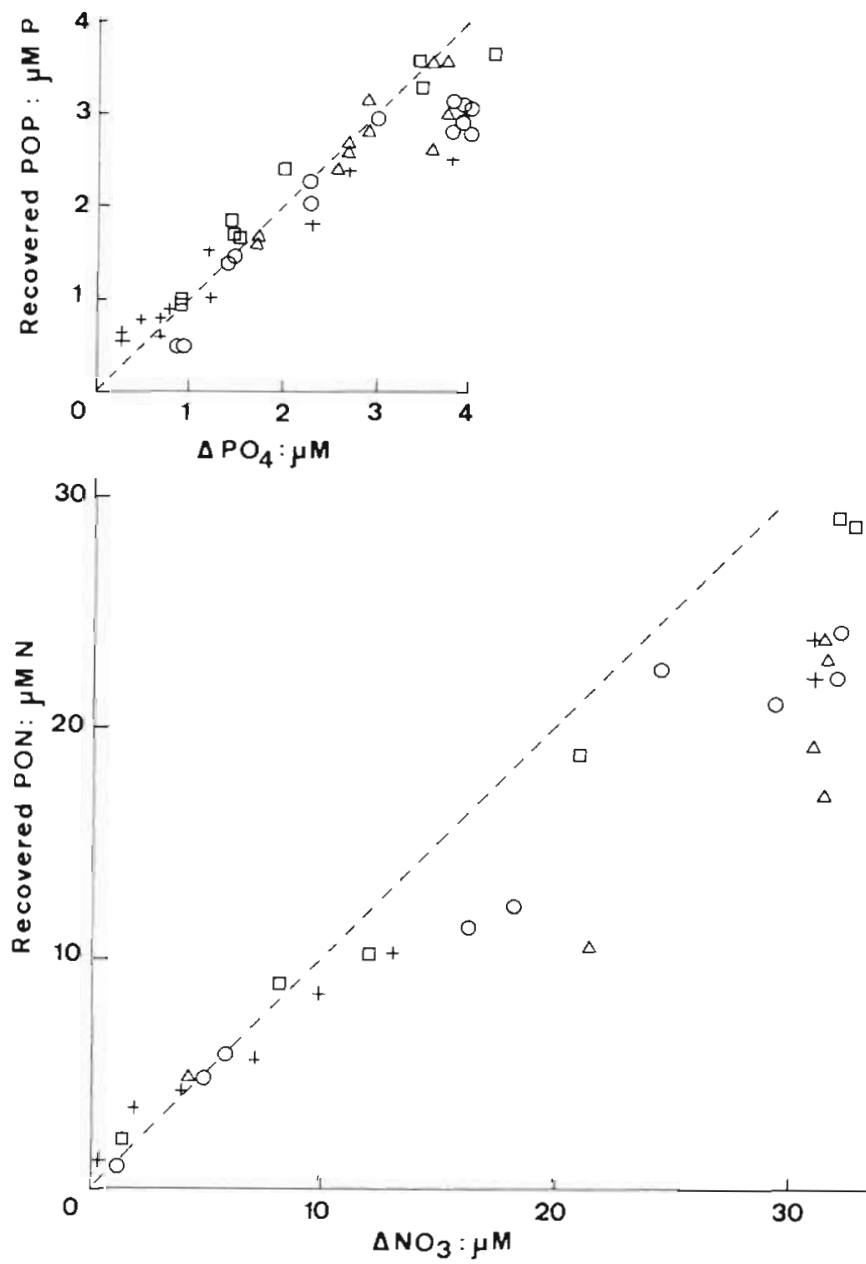

Fig. 3. Comparison between the consumption of nitrate $\left(\Delta \mathrm{NO}_{3}\right)$ and phosphate $\left(\triangle P O_{4}\right)$ and the recovery of $N$ in $P O N$ and $P$ in $P O P$ by the new reagent during growth of different phytoplankton cultures (+, Synechococcus sp.; $\square$, Phaeodactylum tncornutum; $\Delta$, Dunaliella tertiolecta; 0 . Tetraselmis maculata). The dashed line indicates $100 \%$ recovery

related to the chlorophyll biomass. PON/POP ratios were close to the Redfied ratio (15) in superficial water, but decreased with depth. The value dropped to below 10 when chlorophyll concentration became very Iow $\left(<0.02 \mu \mathrm{g}^{-1}\right)$ This decrease of the PON/POP ratio with depth could be due to changes in seston composition, becoming dominated by detritical materials and bacteria that have lower PON/POP ratio than phytoplankton (respectively 6.4 and 3.2; Downing \& McCauley 1992).

The procedure was also applied to following changes in PON or POP phytoplankton cultures growing on $\mathrm{NO}_{3}$ or $\mathrm{PO}_{4}$ for several days (Fig. 3). An impression of the reliability of the proposed method is given by the reproducible $100 \%$ recovery of NO3 and PO4 absorbed during the first phase of growth. At the end of the exponential growth, a great discrepancy between $\mathrm{NO}_{3}$ or $\mathrm{PO}_{4}$ disappearance and PON and POP was noted. Such lack of particulate matter during phytoplankton growth in batch culture has previously been observed by Raimbault \& Slawyk (1991) and related to an increase in dissolved organic matter in the culture medium. By direct measurements of dissolved organic nitrogen (DON) during the growth of a culture of Synedra planctonica on nitrate, Collos et al. (1992) showed an important DON release like this. This discrepancy was more evident for nitrogen than for phosphorus, indicating that phytoplankton excrete organic matter which should be relatively richer in nitrogen than in phosphorus (Fig. 3). The N/P ratios measured in the particulate matter (PON/ POP) at the end of the culture were below 16 (Table 1). These low values, around 8 to 10 (i.e. lower than the Redfield ratio), seem to be characteristic of numerous phytoplanktonic algae growing under nutrient-sufficient conditions in batch culture (Rhee \& Gotham 1980) or in a eutrophic coastal environment (Ryther \& Dunstan 1971).

This rapid technique is very suitable for shipboard analysis and will be a valuable tool in future aquatic nutrient studies, to evaluate nitrogen-phosphorus relationships in different oceanic and freshwater ecosystems, particularly in oligotrophic environments, which for their characterisation need numerous and precise determinations.

Acknowledgements. We thank N. Garcia for the CHN analyses and his assistance during laboratory work. We are grateful to M. C. Bonin for drafting and contributing data from the literature. This study was supported by the J.G.O.F.S program.

\section{LITERATURE CITED}

Collos, Y., Döhler, G., Biermann, I. (1992). Production of dissolved organic nitrogen during uptake of nitrate by Synedra planctonica: implications for estimates of new production in the oceans. J. Plankton Res. 14(8): 1025-1029

Downing, J. A, McCauley, E. (1992). The nitrogen:phosphorus relationship in lakes. Limnol. Oceanogr. 37(5): 936-945

Ebina, J., Tsutsui, T., Shirai, T. (1983). Simultaneous determination of total nitrogen and total phosphorus in water using peroxodisulphate oxidation. Wat. Res. 17: $1721-1726$

Hosumi, M., Sudo, R. (1986). Simultaneous determination of total nitrogen and total phosphorus in freshwater samples using persulfate digestion. Int. J. environ. Stud. 27 : $267-275$

Johnes, P. J., Heathwaite, A. L. (1992). A procedure for the simultaneous determination of total nitrogen and total phosphorus in freshwater samples using persulphate mucrowave digestion. Wat. Res. 26(10): 1281-1287

Koroleff, F. (1983). Determination of total nitrogen and phos- 
phorus. In: Grasshof, K., Erhardt, M., Kremiing, K. (eds.) Methods for seawater analysis, 2nd edn. Verlag Chemie, Weinheirn, p. 162-173

Langner, C. L., Hendrix, P. F. (1982). Evaluation of a persulphate digestion method for particulate nitrogen and phosphorus. Wat. Res. 16: 1451-1454

Menzel, D. W., Corwin, N. (1967). The measurement of total phosphorus in sea water based on the liberation of organically bound fractions by persulfate oxidation. Limnol. Oceanogr. 10(2): 280-282

Raimbault, P., Rodier, M., Taupier Letage, I. (1988). Size fraction of phytoplankton in the Ligurian Sea and the Algerian Bassin (Mediterranean Sea): size distribution versus total concentration. Mar. microbiol. Fd Webs 3: 1-7

Raimbault, P., Slawyk, G. (1991). A semi-automatic, wetoxidation method for the determination of particulate

This note was submitted to the editor organic nitrogen collected on filters. Limnol. Oceanogr 36: $405-408$

Rhee, G. Y., Gotham, 1. J. (1980). Optimum N:P ratios and coexistence of planktonic algae. J. Phycol. 16: 186-189

Ryther, J., Dunstan, W. M. (1971). Nitrogen, phosphorus and eutrophication in the coastal marine environment. Science 171: $1008-1013$

Strickland, J. D. H., Parsons, T R. (1972). A practical handbook of seawater analysis, 2 nd edn. Bull. Fish. Res. Bd Can. 167

Tréguer, P., Le Corre, P. (1975). Manuel d'analyses des sels nutritifs dans l'eau de mer. Laboratoire d' Océanographie chimique, Univ. de Bretagne Occidentale, Brest

Valderrama, J. C. (1981). The simultaneous analysis of total nitrogen and total phosphorus in natural water. Mar. Chem. 10: 102-122

Manuscript first received: June 28, 1993

Revised version accepted: December 8, 1993 